\title{
Optimization of Municipal Solid Waste Collection System in Hefei City of China
}

\author{
Shouchuang Hu${ }^{1}$, Jun Chen ${ }^{2}$, Ke Wu ${ }^{3 *}$, Zhongkai Zhou' ${ }^{1}$, Tingting Cheng1, Dongbiao \\ $\mathrm{Wu}^{4}$ \\ 1- Department of Biological and Environmental Engineering, Hefei University, Hefei 230601, P. R. China. \\ 2- Anhui Key Laboratory of Sewage Purification and Ecological Rehabilitation Materials, Hefei 230601, \\ P. R. China. \\ 3- Collaborative Innovation Center for Environmental Pollution Control and Ecological Restoration of Anhui \\ Province, Hefei University, Hefei 230601, P. R. China. \\ 4- Anhui Urban Construction Design Institute Co., Ltd., Hefei 230051, P. R. China. \\ Address: No. 99, Jinxiu Road, Hefei 230601, P. R. China. *Corresponding author. E-mail: wuke@hfuu.edu.cn
}

\begin{abstract}
The refuse collection spot is the central part in the municipal solid waste collecting system. The wrong collecting way would lead to environmental problem and disturb the life of citizens. With the demand of source separation in China, the waste collecting sites need to be improved. Nowadays there have three different types of wastes collecting in Hefei, capital city in Anhui province, China. The advantages and disadvantages of such waste collection system were compared and discussed. The suggestions were put forward. Concerning about special example for agricultural market waste collection, taking Hefei Wanguo market as a sample, the research was made to optimize the present collection system. Compared with traditional waste collecting sites, the results showed the agricultural market waste collecting sites were better in both environmental and social efficiency.
\end{abstract}

Keyword: solid waste collection, market, changes.

\section{INTRODUCTION}

Hefei is the capital city of Anhui province in China. It refers as the center of provincial politics economy culture education and transportation. Hefei is also the city in the center of Anhui in geography. The area of the city is about 11445.1 square kilometers, the population is 7.79 million. The development of economy in Hefei is rapid, it produces large amount of solid waste, about 3616 tons, each day. According to the prediction, the output of solid waste will increase to 2.22 million tons in 2030 [1]. In fact, the Hefei city collected the solid waste daily since 1997 [2]. Moreover, the city achieved the waste direct from household in package gradually, making use of it in an environmental way. In 2000, the domestic garbage disposal fee was implemented [3].

So much solid waste may be a burden to Hefei city, but if appropriate collection system and technology can be choosed, it not only can make waste profitable, but also can produce enormous economic benefits. So this paper studied the present solid waste collection system in Hefei and tried to find a suitable municipal solid waste collection mode.

\section{MATERIALS AND METHODS}

\section{A. Materials}

In order to analyse the physical component of municipal solid waste in Hefei, we sampled municipal solid waste from eight districts and the materials of analysis are including the following three.

1 -sample sieve : diameter of the hole is $10 \mathrm{~mm}$

2 -scale: the minimum division value is $50 \mathrm{~g}$

3 -Platform scales : the minimum division value is $5 \mathrm{~g}[4]$

B. Methods

Method for sampling and analysis is The National Standard of the People's Republic of China, sampling and analysis method for municipal solid waste. The standard provides that physical component analyse must be done immediately after sampling, otherwise, the samples must be paved on the clean concrete floor with impermeable plastic in the shatered and shady room, the thickness is limited within $50 \mathrm{~mm}$. And in case of the loss of samples and mixture of other substance, it must be prevented within $24 \mathrm{~h}$. The physical component analyse are including six steps. [4]

1 -Weigh the sample of municipal solid waste

2 -Sort the ingredients of municipal solid waste samples according to the categories in the standard

3-After sorting, the remaining samples are fully sieved, and then subdivide.

4-Easy to be dismantled should be disassembled before classification

5-Determine whether to subdivide according to the purpose of the measurement 
6-The last step, weigh the weight of each component

The physical components of household waste are calculated as follows

$$
\begin{gathered}
C_{i}=\frac{M_{i}}{M} \times 100 \\
C_{i}^{\prime}=C_{i} \times \frac{100-C_{i(w)}}{100-C_{(w)}}
\end{gathered}
$$

$C_{i}$-Wet base content of a component (\%)

$M_{i}$ - Wet base weight of a component $(\mathrm{KG})$

$M$ - Total weight of sample (KG)
$C_{i}^{\prime}$ - Dry base content of a component (\%)

$C_{i(w)}$ - Moisture content of a component (\%)

$C_{(w)}$ - Sample moisture content (\%)

Results retain two significant digits.

\section{RESULTS AND DISCUSSION}

C. Experimental results

The physical components of municipal solid waste in Hefei are shown in Table 1. From the table we can see that organic waste is a large percentage, about $70 \% \sim 80 \%$ and inorganic waste is about $20 \%$.

Table 1

\begin{tabular}{|c|c|c|c|c|c|c|c|c|c|c|}
\hline location & $\begin{array}{l}\text { Kitchen } \\
\text { waste }\end{array}$ & Paper & Plastic & Rubber & Textiles & $\begin{array}{l}\text { Wood } \\
\text { and } \\
\text { bamboo }\end{array}$ & $\begin{array}{l}\text { Brick } \\
\text { and tile }\end{array}$ & Glass & Metal & $\begin{array}{l}\text { Lime } \\
\text { soil }\end{array}$ \\
\hline $\begin{array}{l}\text { Yaohai } \\
\text { District }\end{array}$ & 28.43 & 23.37 & 19.56 & 0.94 & 5.24 & 1.34 & 2.73 & 3.68 & 1.14 & 13.58 \\
\hline $\begin{array}{l}\text { Baohe } \\
\text { District }\end{array}$ & 31.36 & 15.72 & 21.03 & 0.77 & 5.68 & 1.65 & 3.04 & 4.15 & 0.72 & 15.90 \\
\hline $\begin{array}{l}\text { Luyang } \\
\text { District }\end{array}$ & 36.46 & 13.20 & 20.55 & 0.91 & 4.81 & 1.54 & 2.32 & 3.84 & 1.51 & 14.87 \\
\hline $\begin{array}{l}\text { Jingkai } \\
\text { District }\end{array}$ & 32.43 & 15.58 & 19.19 & 1.60 & 4.84 & 1.60 & 2.86 & 4.05 & 1.05 & 16.81 \\
\hline $\begin{array}{l}\text { Xinzhan } \\
\text { District }\end{array}$ & 32.20 & 16.81 & 21.00 & 0.81 & 4.76 & 1.49 & 2.82 & 4.16 & 0.85 & 15.09 \\
\hline $\begin{array}{l}\text { Shushan } \\
\text { District }\end{array}$ & 32.80 & 17.25 & 20.77 & 0.80 & 5.60 & 1.51 & 3.05 & 3.54 & 1.04 & 13.66 \\
\hline $\begin{array}{l}\text { Gaoxin } \\
\text { District }\end{array}$ & 34.37 & 16.44 & 16.35 & 1.15 & 5.74 & 1.84 & 2.95 & 3.69 & 0.99 & 16.49 \\
\hline $\begin{array}{l}\text { Zhengw } \\
\text { u District }\end{array}$ & 32.46 & 28.00 & 19.19 & 1.45 & 4.83 & 1.75 & 2.51 & 2.97 & 2.14 & 4.70 \\
\hline
\end{tabular}

The composition of municipal solid waste in hefei (\%)

D. The present collection way of municipal solid waste

The main sources of the daily waste can be classified as residence waste, hotel waste and famers' market waste. At present, the main gathering way in Hefei is using mobile garbage compressor, garbage storage machine and trash can. The terminal treatment technologies for solid waste were complexity. They are incineration technology, landfill and compost [5]-[6]. Different technology guides the different collection way. Fig. 1 shows the present waste collection way in Hefei. At present, the main problem in Hefei is solid waste collected in a mixing way, resulting in resource utilization not very high. With the demand of source separation, the municipal solid waste management should be strengthened, and the municipal solid waste collection sytem should be optimized.

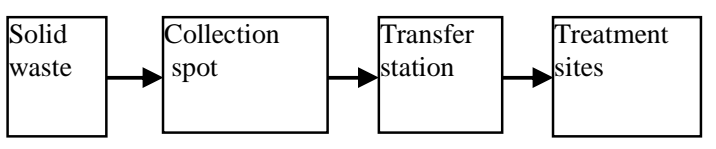

Fig.1. The existing collection system

$E$.

F. Types of municipal solid waste collection system in Hefei

At present, there are three types of garbage collection in Hefei, such as mobile waste collection container; garbage storage machine and trash can. Mobile waste collection box has the functions of loading, compression and transportation municipal solid waste [7]. The garbage storage machine has the functions of collection, storage and automatic unloading [8]. The trash can was used to collect and store solid waste. All of them can be commonly used for urban sanitation collection stations, residential areas, communities, schools and other large public 
places. Three type collection devices shown as Table. 2. Their advantages and disadvantages were listed in Table 3.

TABLE 3

COMPARISON OF THREE COLLECTION WAYS

\begin{tabular}{|c|c|c|c|c|}
\hline $\begin{array}{c}\text { Serial } \\
\text { number }\end{array}$ & Project & Mobile garbage collection & Garbage storage machine & Trash can \\
\hline 1 & Area & Big & Small & Big \\
\hline 2 & $\begin{array}{l}\text { Cost of the } \\
\text { machine }\end{array}$ & $30-50$ million & $25-40$ million & $\begin{array}{l}200 \text { trash cans, to be } \\
40,000 \text { Yuan and often } \\
\text { need to update }\end{array}$ \\
\hline 3 & Sewage & $\begin{array}{l}\text { Less and filter before } \\
\text { discharge into the sewage } \\
\text { pipe network }\end{array}$ & $\begin{array}{c}\text { Less and filter before } \\
\text { discharge into the sewage } \\
\text { pipe network }\end{array}$ & $\begin{array}{c}\text { More and } \\
\text { discharged arbitrarily }\end{array}$ \\
\hline 4 & $\begin{array}{l}\text { Applicable } \\
\text { conditions }\end{array}$ & Indoor or outdoor & Indoor or outdoor & outdoor \\
\hline 5 & $\begin{array}{c}\text { Supporting } \\
\text { vehicles }\end{array}$ & $\begin{array}{l}\text { Detachable container } \\
\text { garbage collector }\end{array}$ & Truck with compactor & Truck with compactor \\
\hline 6 & Operation method & Automatic & Automatic & Artificial \\
\hline 7 & $\begin{array}{l}\text { Closed and } \\
\text { compressed }\end{array}$ & $\begin{array}{c}\text { Double confined and } \\
\text { horizontal compression }\end{array}$ & $\begin{array}{l}\text { Double confined and } \\
\text { Horizontal compression }\end{array}$ & $\begin{array}{l}\text { not sealed and } \\
\text { No compression }\end{array}$ \\
\hline 8 & Service life & Designed for 10 years & Designed for 10 years & Need to be updated \\
\hline 9 & Compression ratio & $3: 1$ & $2.5 \sim 3: 1$ & $\begin{array}{c}\text { No compression } \\
\text { capability }\end{array}$ \\
\hline
\end{tabular}

The garbage storage machine and the mobile waste compressor have many advantages, such as easy to operate, container tightness and high degree of mechanization [7]-[8]. The use of environmentally friendly garbage collection points is more conducive to the future clearance work.

G. Optimization of refuse collection spot in Hefei city

With the implementation of source separation project in China, the present municipal solid waste management system faces many challenges. The traditional collection and transportation model should be changed gradually. In China, the popular guide for solid waste source separation from household classified as dry and wet [9], the resident can separate daily waste with different bags in such simple way. The waste source separation action needs the support of treatment technologies. It is important that the separated municipal solid waste can be dealt with next step into a useful cycle to reduce environmental pollution [10].

There are three kinds of technologies, such as incineration, composting and landfill [11], for solid waste treatment in Hefei. The capacities of these waste treatment plants are sufficient to the daily waste disposal. In order to establish a sustainable solid waste management system, appropriate municipal solid waste collection and transportation system is more important. At present, Hefei has been established the city kitchen waste collection and transportation system, the waste produced from hotels, restaurants and cafeteria, etc., by special container collection, is collected and transported directly to the composting plant by the kitchen garbage truck [12], but, the resident solid waste and agricultural market waste are collected together in designed locations, then optimization. Table 4 shows the result. transported by truck to the waste transfer station, and finally be sent to the landfill plant or incineration plant. The mixed collection mode is low resource utilization and unfriendly to the environment. How to separate the waste with large amount of organic fraction from the municipal solid waste maybe a big problem or challenge for government in the larger city.

To buy the vegetable directly from agricultural market is the Chinese tradition. There are many larger scales of agricultural markets in each city in China. Every day a large amount of waste are produced from there. This waste contains mainly organic fraction. It has the characteristics of high water content $(>80 \%)$, high volatile solid content ( $>95 \%$, mass fraction) and high biodegradability [13], according to relevant research, kitchen waste and agricultural market waste can be mixed thermophilic anaerobic digestion [14]. In addition, the waste generated from large famer's market has feasibility of implementing garbage classification [15]-[17]. It is good material for composting. So it is easier to establish the collection and transportation system for agricultural market. As to the resident waste source separation, the idea of "dry and wet" shall be publicized. It will take a few years to practice. Fig. 2 shows the suitable way for municipal solid waste management in the future for Hefei city.

The practice for agricultural market waste collection was investigated. In Hefei binhu new district, Wanguo agricultural market collection point was used as research object. Wanguo farmers market is called "super vegetable basket project", the daily garbage production is about 10-15 tons. The garbage storage machine was selected to collect the waste. Using the method of comparatively research [8], we select different indexes to compare the effect before and after 
Table 4

Comparison of the effect of collection point before and after optimization

\begin{tabular}{|c|c|c|c|}
\hline $\begin{array}{l}\text { Serial } \\
\text { number }\end{array}$ & Project & Before & After \\
\hline 1 & Area & About $200 \mathrm{~m}^{2}$ & About $40 \mathrm{~m}^{2}$ \\
\hline 2 & Sewage & Sewage any discharge & $\begin{array}{l}\text { Three-level filter into the sewage pipe } \\
\text { network }\end{array}$ \\
\hline 3 & Stench & $\begin{array}{l}\text { Most of the trash cans are open, the } \\
\text { stench smells and spreads wide }\end{array}$ & Very little odor and no overflow \\
\hline 4 & Noise & $\begin{array}{l}\text { Operating time mostly night or early } \\
\text { morning, noisy }\end{array}$ & low noise, meet the national standards \\
\hline 5 & Clearance time & Mostly on night or morning & Not subject to time constraints \\
\hline 6 & City appearance & Affect the image of the city & $\begin{array}{l}\text { Integrated with the surrounding buildings, } \\
\text { become the highlight of the city }\end{array}$ \\
\hline 7 & Citizen Complaints & Often complained by residents & No complaints, be praised \\
\hline 8 & Operating efficiency & Low & Higher \\
\hline 9 & Economy & Uneconomical & Good economy \\
\hline
\end{tabular}

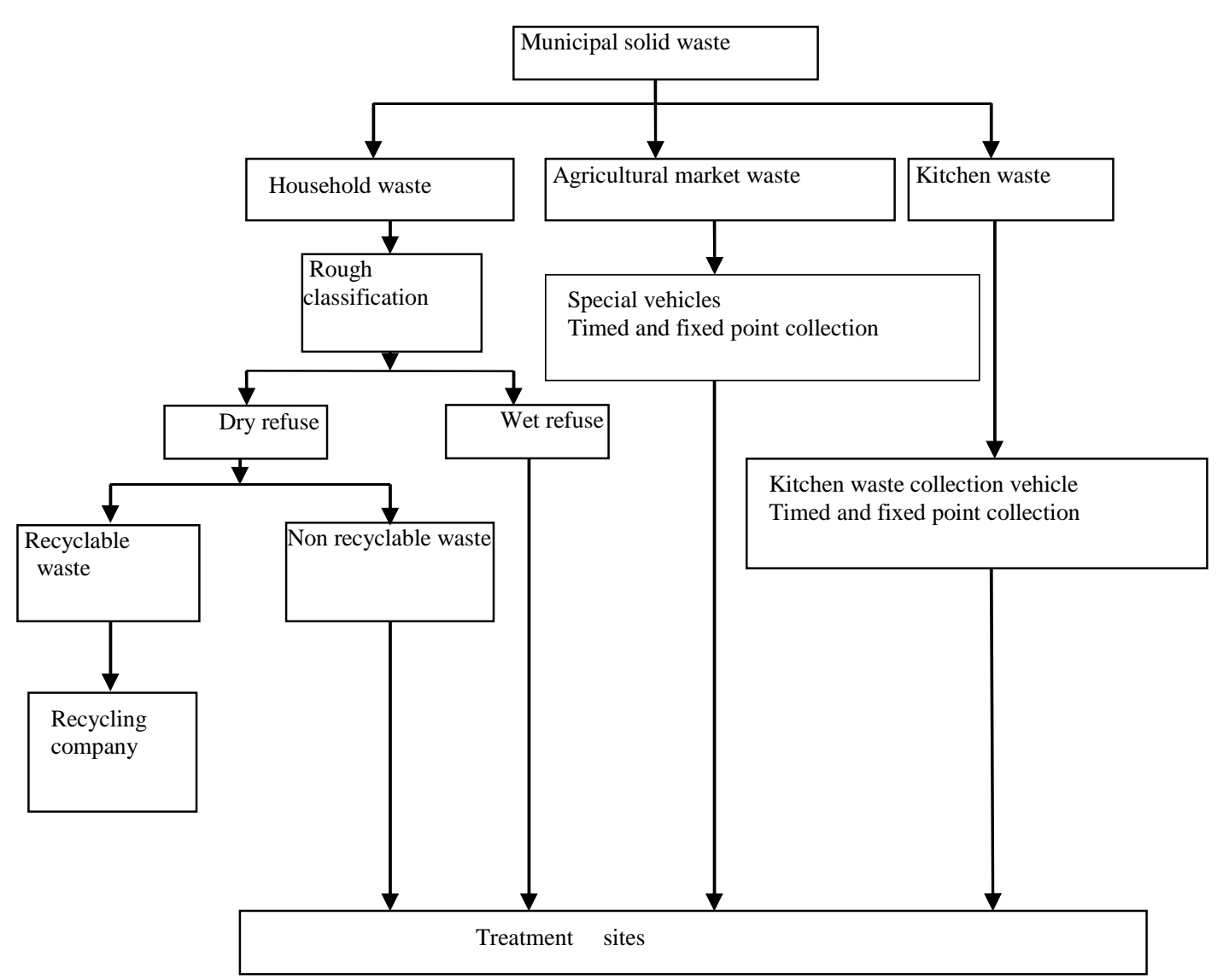

Fig.2 Refuse management optimization

\section{CONCLUSION}

Hefei classification work of solid waste can be taken from easy to difficult. At present, Hefei has established a kitchen waste management system from source collection to terminal processing, and it will be gradually improved. On the basis of the Hefei Wanguo agricultural market research, the new mode is suitable 
Environment. Technology. Resources, Rezekne, Latvia Proceedings of the $11^{\text {th }}$ International Scientific and Practical Conference. Volume III, 97-101

and can be popularized. The heavy difficult point of Hefei city is still built a good system of household waste classification management and it also has a long way to go.

\section{ACKNOWLEDGMENTS}

This research was supported by Municipal Solid Waste Disposal Innovation Team of Anhui Province ([2015]49), Collaborative Innovation Center for Environmental Pollution Control and Ecological Restoration of Anhui Province ([2014]28), the project of Key University Science Research Project of Anhui Province (KJ2016A877).

\section{REFERENCES}

[1] Shu Y. Grey model predication of urban refuse in Hefei city. Environmental Science and Management 9.2007, pp. 5- 8. (In Chinese)

[2] Ye S.Y., Sun S. Q., Wu K. Consideration of all location and construction of municipal solid waste transportation stations in Hefei. Environmental Science and Management 32.2007, pp. 1- 4. (In Chinese)

[3] Wu K., Cai J.M., Yu Z.M., et al. Status and perspective of municipal domestic waste management in Hefei city. Environmental Sanitation Engineering 13.2005, pp. 4- 6. (In Chinese)

[4] Sampling and analysis method for municipal solid waste, 2009, CJ/T313- 2009. (In Chinese)

[5] Yang L., Wang L.C., Zhu X.C. A study on the present management and strategy of MSW in Nanjing city. Sichuan Environment 4. 2001, pp. 529- 529. (In Chinese)

[6] Wu K, Yu Z.M., Jin J., et al. A discussion of selection of schemes for municipal solid waste treatment in Hefei City. Journal of Hefei University 18. 2008, pp. 56- 58. (In Chinese)
[7] Deng W.C. Improvement meat of sealing structure of unloading door of mobile garbage compressor, Equipment Manufacturing Technology 9. 2015, pp. 222- 223. (In Chinese)

[8] Lian X.J., D Y.P., Tian Y. The design of a new kind of garbage compressing and storing device. Development \& Innovation of Machinery \& Electrical Products 21.2008, pp. 121- 122. (In Chinese)

[9] Xu J.X. Research on pilot phrase of dry and wet waste sorting collection in pudong new area. Journal of Green Science and Technology 9.2011, pp. 118- 120. (In Chinese)

[10] Wu K., Yu Z.M., Jin J., et al. Recycle and utilization of municipal solid waste in Hefei. China Resources Comprehensive Utilization 26. 2008, pp. 23- 25. (In Chinese)

[11] Liu S.P., Cai J.M., Wu k., Jin J.status and count measure of municipal solid waste treatment. Journal of Hefei University 15. 2005, pp. 53- 57. (In Chinese)

[12] Gong C. Study on hefei city kitchen waste collection and transportation system. Hefei University, 2015. (In Chinese)

[13] Wang S.R., Zhan M.L., Sun Y.J., et al. Study on thermophilic anaerobic digestion of vegetable market waste in Qingdao. Environmental Pollution \& Control 33. 2011, pp. 39-43. (In Chinese)

[14] Zhan M.L., Dong L., Sun Y.J., et al. Study on thermophilic anaerobic digestion of mixture of kitchen wastes and vegetable market wastes in Qingdao. Chinese Journal of Environmental Engineering 7. 2013, pp. 1945- 1950. (In Chinese)

[15] Gunaseelan V N. Anaerobic digestion of biomass for methane production: a review. Biomass and bioenergy 13 1997, pp. 83-114.

[16] Wang Y.Y. Research on process parameters of anaerobic fermentation of vegetable waste for biogas production and comprehensive utilization of anaerobic fermentation residues. Shanghai Jiao Tong University, 2008. (In Chinese)

[17] Ma Z.D. Research on the vegetable market waste in its reduce and reuse. Suzhou University, 2014. (In Chinese) 